Choirul Mahfud/ Ta’dib: Jurnal Pendidikan Islam, Vol. 8 No. 2 (2019) 618-625

ISSN 1411-8173 | E-ISSN 2528-5092

https://ejournal.unisba.ac.id/index.php/tadib/article/view/5223

\title{
THE PARADOX OF ISLAMIC EDUCATION IN INDONESIA
}

\author{
Choirul Mahfud \\ Institut Teknologi Sepuluh Nopember, Surabaya \\ Email: choirul.mahfud@its.ac.id
}

DOI: $10.29313 /$ tjpi.v8i2.5223

Accepted: October 15th, 2019. Approved: November 19th, 2019. Published: November 19th, 2019

\begin{abstract}
Discussing today's Islamic education in Indonesia can be seen from an optic of politics of curriculum and policy in the politics of education. As we know that the reality of replacing the minister is always followed by replacing policy. Here, indeed, many people do not mean allergy or anti-change as long as the changes are still in the context of continuity and toward the better or the best. So, maybe no worries for all. In this paper, the focus of discussion is focused on important and interesting questions about how is the portrait of Islamic education in Indonesia? How the goals and the Quo Vadis of curriculum policy of Islamic education in Indonesia? How idealism education policy widely in Indonesia? How are the challenges and solutions for Islamic education problems in Indonesia? The paper is written by using qualitative data which is based on references and books literature, newsletters, journals and opinions in the mass media and other sources that are relevant in the study of Islamic education in Indonesia, particularly related to curriculum and education policy. The results showed that: first, a portrait of Islamic education in Indonesia from pre-independence to the independence of Indonesia continues to date indicating a paradox, besides the significant development and progress. Second, the goals of the policy of the Islamic education curriculum in Indonesia are always influenced by government policies at the same general education policy. How idealism education policy widely in Indonesia is the mainstreaming of education as a commander (education is king). Moreover, education policy is not merely to discuss the practice of education and learning, more than that is also concerned with the development of education in the competition at the same time the international synergies. Fourth, the challenges and solutions of Islamic education problems in Indonesia can be seen in terms of internal and external context. The solutions are about the culture of competitiveness balanced with the cooperation with all stakeholders need to be done for the goodness and the nation's welfare.
\end{abstract}

Keywords: Islamic Education; Politics of Curriculum and Policy in Educational Politics

\begin{abstract}
Abstrak
Membahas pendidikan Islam saat ini di Indonesia dapat dilihat dari optik politik kurikulum dan kebijakan dalam politik pendidikan. Seperti kita ketabui bahwa realitas penggantian menteri selalu diikuti dengan penggantian kebijakan. Di sini, memang, banyak orang tidak bermaksud alergi atau anti-perubahan asalkan perubahan masih dalam konteks kontinuitas dan menuju yang lebib baik atau yang terbaik. Dalam tulisan ini, fokus diskusi difokuskan pada pertanyaan-pertanyaan penting dan menarik tentang bagaimana potret paradoks pendidikan Islam di Indonesia? Bagaimana tujuan dan Quo Vadis tentang kebijakan kurikulum pendidikan Islam di Indonesia? Bagaimana idealisme kebijakan pendidikan secara luas di Indonesia? Bagaimana tantangan dan solusi untuk masalah pendidikan Islam di Indonesia? Makalah ini ditulis dengan menggunakan data kualitatif yang didasarkan pada referensi dan buku literatur, buletin, jurnal dan opini di media massa dan sumber-sumber lain yang relevan dalam studi pendidikan Islam di Indonesia, terutama yang berkaitan dengan paradoks pendidikan Islam. Hasil penelitian menunjukekan bahwa: pertama, potret pendidikan Islam di Indonesia dari pra-kemerdekaan bingga kemerdekaan Indonesia hingga saat ini menunjukkan paradoks, di samping perkembangan dan kemajuan yang signifikan. Kedua, tujuan kebijakan kurikulum pendidikan Islam di Indonesia selalu dipengarubi oleh kebijakan pemerintah pada kebijakan pendidikan umum yang sama. Bagaimana idealisme kebijakan pendidikan secara luas di Indonesia adalab pengarusutamaan pendidikan sebagai panglima. Selain itu, kebijakan pendidikan tidak hanya membahas praktik. pendidikan dan pembelajaran, lebib dari itu juga berkaitan dengan perkembangan pendidikan dalam kompetisi sekaligus sinergi internasional. Keempat, tantangan dan solusi masalah pendidikan Islam di Indonesia dapat dilihat dari segi konteks internal dan eksternal. Solusinya adalah tentang budaya daya saing yang seimbang dengan kerja sama dengan semua pemangku kepentingan yang perlu dilakukan untuk kebaikan dan kesejabteraan bangsa.
\end{abstract}

Kata Kunci: Pendidikan Islam; Politik Kurikulum dan Kebijakan dalam Politik Pendidikan. 


\section{INTRODUCTION}

Henry A. Gir Oux stated that pedagogy offers an articulator concept for understanding how power and knowledge are configured in the production, reception, and transformation of subject positions, forms of ethical addresses, and desired versions of future human communities. Here, Henry A. Giroux's phrase illustrates that education has relations with various aspects of human life, including politics. When examined, the ideals and reality of education in Indonesia from the past until now are still often trapped between curriculum politics and education politics (Azra, 2002) (Assegaf, 2003) (C. Mahfud, 2016). The phrase change minister changes policy is not a major problem. But often the problem is almost always experienced and done by every minister of education in Indonesia from the regime to regime political decision-making about curriculum (C. Mahfud, 2016)(C. M. Mahfud, 2019).

A few researchers for education told that solving the problem of priority education in this country that needs and must be addressed is not just about the curriculum. The main subject is the whole matters relating to the political policies of education for justice, welfare and the advancement of the Indonesian people. In the historical record of Indonesia's education since independence until today, the Indonesian government represented by the minister of education seems to only focus (not to be said to be trapped) to always make curriculum changes. We also knew that has minimally occurred 12 times the curriculum changes over the years. Starting from the curriculum in 1947, 1952, 1964, 1968, 1973, 1975, 1984, 1994, 2004, 2006, 2013 and now curricula have returned to the curriculum in 2014 with 2006 , and maybe continue to the next.

From the data and facts above, it can be observed that periodically three political regimes in Indonesia make changes in the education curriculum in Indonesia, namely the change of curriculum in the era of the Old Order, New Order and Reform Order. In the Old Order era when President Soekarno took the lead, there had been 3 changes to the curriculum, namely (Curriculum) 1947 Lesson Plans, (Curriculum) 1964 Primary School Education Plans and 1968 Primary School Curriculums. Then, in the New Order era when President Soeharto in curriculum power, has occurred 5 times a change of curriculum (the curriculum Development School Pilot Project or PPSP, 1973, 1975, Primary School curriculum, 1984, curriculum 1994 and the Revised curriculum 1994 in 1997.

In the reform era, there have been 4 curriculum changes, namely the Competency-Based Curriculum Pioneers (KBK) in 2004, the Curriculum Unit Levels (KTSP) in 2006, 2013 curriculum based on character, science and technology and now the 2014 curriculum with the return to the curriculum 2006, namely KTSP. The question here is, until when will our minister of education always talk partially about education, which seems to only focus on curriculum problems? Why not talk about education from the aspect of a more comprehensive and holistic political education policy? More focus again, in this paper, the discussion focused on the important and interesting questions about how the portrait of upbringing Islamic education in Indonesia? What is the political policy of the Islamic education curriculum in Indonesia? What is the broad political education policy in Indonesia? What are the obstacles and solutions to the problem of Islamic education in Indonesia?

\section{RESULT AND DUSCUSSION}

The results of the study show that: first, a portrait of Islamic education in Indonesia from pre-independence to 
independent Indonesia continues to the present shows significant development and progress. The quantitative data shows that the number of Islamic education institutions is increasing. Qualitatively, trends in the quality of Islamic education also began to rise along with the existence of a national accreditation policy. Second, the political policy of the Islamic education curriculum in Indonesia has always been influenced by the government's political policies as well as general education political policies. Third, the broad political education policy in Indonesia is the mainstreaming of education as the commander (education is king). More than that, the political policy of education is only open to discussing the practice of education and learning, more than that it also cares about the development of education in competition as well as international synergy. Fourth, the obstacles and solutions to the problems of Islamic education in Indonesia can be seen from the internal and external sides. The solution is, of course, the cooperation of all parties needs to be done for the good and progress of the nation.

Here, discussing Islamic education in Indonesia cannot be separated from aspects of government political policy from time to time. In this case, many people ask why education policy is important? Nur Syam considered that this question might not only come from a few people but could come from anywhere. The main problem, according to Nur Syam, is that from the decision $m$ is there a change in the mindset of the country's elite or a decision-maker to make a fundamental change in the concept of equitable education (C. Mahfud, 2016). Within this framework, Nur Syam offers a solution that is needed by the Indonesian education is how to formulate policies that are not ego-sectoral education, but to look at education as a whole and integrative thus obtained remarkable progress.
Abd. Rachman Assegaf (Assegaf, 2003) in the book Internationalization of Education; Sketch a Comparison of Education in Islamic and Western Countries, explains at length the level of comparative education in the Muslim and non-Muslim world as well as showing the important direction of an ideal country's education goals (Assegaf, 2003). In this case, Zamroni in the book of Paradigm of Education in the Future, explains that education in the future is very much influenced by the perspective or paradigm of thinking of education practitioners and stakeholders today. If today's perspective is good and right, then we can be sure that a country's education is better.

Azyumardi Azra in the book Islamic Education: Tradition and Modernization Towards the New Millennium, also confirms that there are considerations of the tradition and modernization of Islamic education to develop the nation in the millennium era. Education certainly does not only pay attention to good traditions but also modernization as a movement of mental revolution and the revolution of the knowledge of the people in the life of the nation and state (Azra, 2002).

In this context, talk of education is very related to political power. HAR Tilaar in his book on Power and Education reveals the veil of the relationship between education and power from time to time which is very closely happening at various levels from the bottom to the top (Tilaar, 2003). One example of the relationship between education and power is a matter of discussion which is almost always interesting and may be confusing in the theme of education, which is related to the curriculum and all its changes and their reasons. However, efforts to change the curriculum in Indonesia are often disputed because it is more considered to reflect the interests of the ruling elite or the government rather than the interests of the education community as a whole. Also, the 
process of curriculum change is considered always lacking mature planning, without a comprehensive evaluation, lack of continuity, too fast and even allegedly too political. As a result, less than the maximum level of implementation or implementation in the field (Boyd, 1994) (Demaine, 2004).

Discussion of changes for curriculum development is a comprehensive term, including at least: planning, implementation, and evaluation. Irma Alhanaah as revealed in his writing that curriculum planning is the first step to build a curriculum when curricula workers make decisions and take action to produce a plan that will be used by teachers and learners. Whereas the application of curriculum or commonly called curriculum implementation, according to Irma, focuses more on trying to transfer curriculum planning into operational action. Then the evaluation of the curriculum, according to him, the final stage of development of the curriculum to determine how big the learning outcomes, the level of achievement of programs that have been designed, and the results of the curriculum itself. Ideally, Irma stated that curriculum development involves not only the people who are directly related to the world of education, but in them involve many people, such as politicians, entrepreneurs, parents of students, as well as elements of society who feel an interest in education (Khambali, 2017) (Freire, 1985).

We know that a curriculum practiced by teachers according to their experience and knowledge related to the way, techniques, and content of learning materials. In this context, talking main issue of education should start from the issues related to political policy of education as a whole, ranging from regulations that $s$ clearly associated with a system of institutional policy of providing education, budget policy, welfare educator/ teacher, until the policy educational system for all in accordance with the mandate of the 1945 Constitution.

HAR Tilaar and Riant Nugroho in the book "Education Policy", stating that educational policy is part of an important public policy related to education is the responsibility of government to its citizens. This political education policy usually focuses on strategic and comprehensive policy issues regarding education for the advancement, welfare, justice, and intelligence of Indonesian people as a whole. Thus, education political policy is a central and essential policy that must be prioritized and get priority in national policy (Nugroho, 2008).

It is time for education to be made commander (education is the king), not like in the New Order era that glorifies the economy as commander (economics is the king) and also in the Old Order era which made political ideology as commander (political ideology is the king) in life nation and state which results in the slow progress of the nation and the low quality of the quality of Indonesia's human resources.

Education policy-making process in this country is already should be understood by the educators, scholars and politicians, ministers of education and stakeholder. We have optimism that all stakeholders willing to "sit down together" to solve the problem of political education in the country. In the era of President Jokowi's leadership, all elements of the education community certainly hope that the political policies of education can no longer be defeated by curriculum policy politics and moreover policies in other sectors outside of education.

In the history of Islam, for example, the relationship between education and politics can be traced back to the most fertile times of growth in Islamic educational institutions. Sirozi in the book Politics Education states that throughout history there was a very close relationship between politics and Islamic education. 
This fact can be seen from the establishment of several Islamic institutions in East puffing that sponsored by the political authorities. The most famous example according to Sirozi is the establishment of the Nizhamiyah madrasa in Baghdad which was founded around 1064 by the Seljuq Vizier, Nizham al-Mulk (Rachman, 2007).

From this, it can be understood that Islamic education has many functions and goals. Muhtarom in his article entitled " Islamic and Political Education" stated there are several functions and objectives including: First, Islamic education as a vehicle for religious interests and a means of maintaining Islamic identity. Second, Islamic education as a means for the political interests of the authorities. Third, Islamic education as a means of giving birth to good citizens. Fourth, Islamic Education as a vehicle for the nation's elite childbirth. Fifth, Islamic education as a vehicle to give birth to high politics (noble politics).

We also understand that the functions and political objectives of education are at least from the two statements of David Easton in his famous article The Function of Formal Education in a Political System and Thomas H. Eliot in his article in American Political Science Review. According to Easton that educational institutions play important political functions and prove briefly as social-political agents (Cross, 2004) (Gorham, 1992). Eliot demonstrated political aspects at the local level. He said that like it or not, school administrators involved in politics because the local schools are a unit rule. Eliot stressed that politics includes making government decisions, and efforts or struggles to obtain or maintain power to make those decisions. Public schools are part of the government. Therefore this institution is a political entity.
Dale and Apple (1989) see the political function of education from state relations and education. Both of them found that school became one of the objects of modern politics where we could see how awareness and certain hegemony developed. Wiles Bondi as quoted by Sudrajat (2008) in his book 'Curriculum Development: A Guide to Practice ' also explains the political influence in the formation and development of the curriculum. This clearly shows that curriculum development is influenced by political processes. Likewise in the practice of Islamic education in Indonesia in general (Bobbi De Porter dan Mike Hernacki, 1992).

The case of the practice of political education in Islam if not watched out by all parties can lead to unwanted politicization practices. In Madura, in each ahead of local elections, there is always a case of politicization pesantren Kiai characterized by using attributes specific to the interests of the political elite to be elected as local political leaders. This also happened in regions throughout Indonesia. It could be said that boarding schools across Indonesia are always filled with thorny problems that are difficult to avoid, namely the practice of politicization, especially in any momentum of democracy celebration or election. In East Java, for example, even though the election of the governor and deputy governor has been held for a long time, it does not mean that pesantren institutions are safe from the practice of politicization. Moreover, in 2015 and the upcoming 2019 celebration will be held by national elections to choose the president and vice president and member of parliament (DPR) and the region (DPD).

The results of my dissertation research in a doctoral program found some interesting facts that after the reform of Islamic boarding schools in this country was never devoid of politicization. It is listed as an Islamic educational institution 
that is most often the object of politicization. The politicization of schools in this country did not escape the role and influence of various parties, including politicians, Kiai, students and alumni of pesantren. Thus, the politicization of schools not only by the political elite just as the element of "outsider", but also there is an element of " insider" performed by kiai, students and alumni students of pesantren in this country (Mukminin \& Habibi, 2019).

In practice, the politicization of pesantren is indeed more often dominated and carried out by the political elite than the kiai and his alumni. If there is involvement of pesantren kiai who go into politics, usually because they are tempted by several lures and practical political promises to help develop pesantren. While pesantren alumni who participated in the practice of politicization of schools usually engage in one successful team of the political elite in particular, or maybe alumni of pesantren the candidates running for public office, both at the executive and legislative branches (Buchori, 2001; Cooper, et.all. 2008).

From this, it can be predicted the possibility of pesantren politicization practices which (will) be re-done in every democratic party event. What could happen? The reasons are certainly very diverse, at least the arguments of several political elites in seeing pesantren can be understood from the following reasons. First, pesantren are considered to have the strength of a large mass base consisting of santri and alumni networks that are spread everywhere, so that they can be used as sound-panning machines. Second, schools still are the center of most of the people students who demonstrated by adherence to kiai as an exemplary figure in the affairs of social politics apart from religion. Third, the pesantren also has a network of pesantren that is driven by the kiai and some pesantren foundation leaders
(Krisdiyanto, Muflikha, Sahara, \& Mahfud, 2019).

Therefore, until now, pesantren still has an appeal for many political elites to gain votes to achieve the desired power interests. Moreover, in quantity, the number of pesantren in Indonesia from Sabang to Merauke now amounts to close to one million. It can be imagined, with such a large number, pesantren have a high bargaining position in the eyes of the political elite. In this context, managers of pesantren in the current era are tested for the thickness of their political faith. Are willing to plunge participate in the democratic party or otherwise participate in party elections. The turmoil of the kiai and pesantren stakeholders is usually increasingly felt when those involved in practical politics are from the insider element, especially the kiai family or pesantren alumni themselves. It would be different if involved in $\mathrm{p}$ o lytic practical element of "outsider" that did not come and is not related at all to the schools concerned.

In certain contexts, the political reasoning of pesantren can usually be understood to be more inclined towards certain kiai patrons. Here, the political elite is no less resourceful to win political sympathy and solidarity from the pesantren by involving the most influential figure in the pesantren. Network utilization is relatively run boarding schools are now beginning to systemically, especially small schools are spreading in some areas (C. Mahfud, 2019)

In general, the practice of pesantren politicization is not a new problem. When $\mathrm{KH}$ Abdurrahman Wahid (Gus Dur) was still alive, for example, the politicization of the pesantren had taken place and it seemed as though no one dared to question it. Then, it was Gus Dur himself who requested that there be no politicization of Islamic boarding schools for short-term political interests. At that time, Gus Dur 
stated that the matter of morals, please follow the scholars. However, the matter of politic should be separated from religious affairs. So, there should be no more politicization of Islamic boarding schools for short-term political interests.

The same thing has also been emphasized by cultural observer Acep Zamzam Noor who stated firmly, that pesantren were damaged by politics. Initially, pesantren gained public trust because it was believed to be an institution that stood above all groups. However, problems began to emerge when parties and political elites began to make pesantren as objects of political action that should be prevented and watched out together. Likewise, the kiai should re-focus on thinking about pesantren seriously so that there are no fears of developing pesantren without kiai.

Another case is the existence of pesantren which is now allegedly involved in spreading religious radicalism. There is a lot of worrying news about pesantren so that the reactive response to pesantren is not only positive but also negative. During this pesantren kiai-centered, all policies of pesantren dependent kiai. Talking about the pesantren curriculum policy always comes from the kiai's policy. The kiai's source usually refers to the experience, understanding, and education he had taken before.

Lately, the government began to intervene in pesantren educational institutions which initially seemed to be only influenced by the kiai as the pesantren owner. Now the government made several policies that could affect the existence of pesantren today and the future. One of those affected by the pesantren is its graduates (output), learning process and curriculum. In this context, Islamic education, whatever its type and whatever the background of its establishment must still be under government control. The government $\mathrm{n}$ this case does have the authority and policy to make progress or vice versa setback of educational institutions in Indonesia, including Islamic educational institutions. From time to time and era to time, government policy is of course still going very well according to the expectations of the community. However, the community and the government certainly continue to hope that in the future it can be better in paying attention to education for the progress and welfare of this country.

\section{CONCLUSION}

Islamic education in Indonesia is largely determined by the country's political policies. In general, there are two faces of education in Indonesia; national-style (national education) and religious-style (Islamic education). Specifically, in discussing Islamic education has a unique in its curriculum characteristics. From here, the debate over the Islamic education curriculum has been running since Indonesia was not yet independent until now. So the curriculum debate is not new but becomes unproductive when it stops in the curriculum. Therefore, currently, the discussion of Islamic education is starting to shift to the political aspects of education. Where a lot of people think about how Islamic education becomes the center and bargaining position in the eyes of the world. Islamic education can help provide solutions to any problems that exist in this country. Also about the idealism of organizing and contributing Islamic education in Indonesia today and later. All hope that any educational institution in this country can go in line with the goals and vision of the intellectual life of the nation. 


\section{REFERENCES}

Assegaf, A. R. (2003). Internasionalisasi Pendidikan. Yogyakarta: Gama Media.

Azra, A. (2002). Pendidikan Islam. Jakarta: Logos Wacana Ilmu.

Bobbi De Porter dan Mike Hernacki. (1992). Quantum Learning. Membiasakan Belajar Nyaman dan Menyenangkan. Bandung: Penerbit Kaifa.

Boyd, D. N. P. A. W. L. (1994). Antipolitics, Education, and Institutional Choice. USA: Sage publication.

Cross, C. T. (2004). Political Education. USA: Teachers College Press-Columbia University.

Demaine, J. (2004). Citizenship and Political Education Today. USA: Palgrave Macmillan.

Freire, P. (1985). The Politics of Education: Culture, Power and Liberation. Massachusetts: Bergin and Garvey Paperback.

Gorham, E. B. (1992). National Service, Citizenship, and Political Education. USA: SUNY Press.

Khambali, K. (2017). Family Role in Shaping Character Islam in Early Childhood Through Habituation Method. Ta'dib: Jurnal Pendidikan Islam. https://doi.org/10.29313/tjpi.v6i1.2382

Krisdiyanto, G., Muflikha, M., Sahara, E. E., \& Mahfud, C. (2019). Sistem Pendidikan Pesantren dan Tantangan Modernitas. Tarbawi: Jurnal Ilmu Pendidikan.

Mahfud, C. (2016). Politik Pendidikan Islam di Indonesia. Yogyakarta: Pustaka Pelajar.

Mahfud, C. (2019). Evaluation of Islamic Education Curriculum Policy in Indonesia. Premiere Educandum: Jurnal Pendidikan Dasar Dan Pembelajaran. https://doi.org/10.25273/pe.v9i1.4016

Mahfud, C. M. (2019). THE GENEALOGY OF SOCIAL HISTORY OF ISLAMIC EDUCATION POLITICS IN INDONESIA. Al-Tadzkiyyah: Jurnal Pendidikan Islam. https://doi.org/10.24042/atjpi.v10i1.385 5

Mukminin, A., \& Habibi, A. (2019). Promoting Access and Success for Disadvantaged Students in Indonesian Basic Education. https://doi.org/10.4018/978-1-52259108-5.ch022
Nugroho, R. (2008). Kebijakan Pendidikan Yang Unggul. Yogyakarta: Pustaka Pelajar.

Rachman, M. F. (2007). Demokrasi Tanpa Kaum Demokrat. Yogyakarta: Koekoesan. 